\title{
Analisis Hukum Peraturan Daerah Tanpa Melalui Tahapan Perencanaan Pembentukan Peraturan Perundang-undangan
}

\section{Legal Analysis of Regional Regulations Without Through the Stage of Planning Forming Regulations}

\section{Erwinsyah Agus ${ }^{1}$, Muhammad Jufri Dewa ${ }^{2}$, Muhammad Sabaruddin Sinapoy ${ }^{3}$}

1. Perancang Peraturan Perundang-undangan Ahli Muda Kantor Wilayah Kementerian Hukum dan HAM Sulawesi Tenggara.E-mail: erwin_syah83@ymail.com

2. Universitas Halu Oleo, Indonesia. E-mail: muh.jufridewa@yahoo.com

3. Universitas Halu Oleo, Indonesia.E-mail: sabaruddinsinapoy@yahoo.com

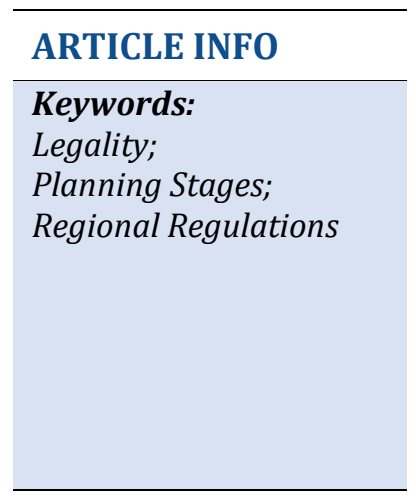

\section{INFO ARTIKEL}

Kata kunci:
Legalitas;
Tahapan Perencanaan;
Peraturan Daerah

Peraturan Daerah

\begin{abstract}
The formation of regional regulations must meet formal and material requirements. Formal requirements, related to the stages of forming a regional regulation. The stages of forming a regional regulation include the stages of planning, drafting, discussing, ratification or enactment and enactment. In this thesis the author focuses on the planning stages of forming a regional regulation that has been regulated in legislation. The drafting goal in this thesis is how the legality of regional regulations without going through the stages of planning the formation regulations and the procedure for canceling regional regulations that do not go through the planning stages of forming regulations.
\end{abstract}

\section{Pendahuluan}

Peraturan daerah merupakan peraturan terendah dalam sistem hierarki peraturan perundang-undangan yang memiliki arti strategis dalam rangka mewujudkan otonomi 
daerah sesuai dengan kebutuhan daerah. Pada prinsipnya ketentuan pengaturan dalam peraturan daerah yang akan mengejawantahkan urusan pemerintahan di daerah.

Pasal 18 ayat (6) Undang-Undang Dasar Negara Republik Indonesia Tahun 1945, bahwa pemerintahan daerah berhak menetapkan peraturan daerah dan peraturan-peraturan lain untuk melaksanakan otonomi dan tugas pembantuan.

Dalam Undang-Undang Nomor 23 Tahun 2014 tentang Pemerintahan Daerah sebagaimana telah diubah beberapa kali terakhir dengan Undang-Undang Nomor 9 Tahun 2015 tentang Perubahan atas Undang-Undang Nomor 23 Tahun 2014 tentang Pemerintahan Daerah dijelaskan bahwa pemerintahan daerah adalah penyelenggaraan urusan pemerintahan oleh pemerintah daerah dan dewan perwakilan rakyat daerah menurut asas otonomi dan tugas pembantuan dengan prinsip otonomi seluas-luasnya dalam sistem dan prinsip Negara Kesatuan Republik Indonesia sebagaimana dimaksud dalam Undang-Undang Dasar Negara Republik Indonesia Tahun 1945. ${ }^{1}$

Sebagaimana diketahui bahwa otonomi daerah adalah hak, wewenang, dan kewajiban daerah otonom untuk mengatur dan mengurus sendiri urusan pemerintahan dan kepentingan masyarakat setempat dalam sistem Negara Kesatuan Republik Indonesia; Sedangkan, tugas pembantuan adalah penugasan dari pemerintah pusat kepada daerah otonom untuk melaksanakan sebagian urusan pemerintahan yang menjadi kewenangan pemerintah pusat atau dari pemerintah daerah provinsi kepada daerah kabupaten/kota untuk melaksanakan sebagian urusan pemerintahan yang menjadi kewenangan daerah provinsi. $^{2}$

Pemberian otonomi yang seluas-luasnya kepada daerah diarahkan untuk mempercepat terwujudnya kesejahteraan masyarakat melalui peningkatan pelayanan, pemberdayaan, dan peran serta masyarakat serta pembentukan peraturan daerah. Di samping itu melalui otonomi luas, dalam lingkungan strategis globalisasi, daerah diharapkan mampu meningkatkan daya saing dengan memperhatikan prinsip demokrasi, pemerataan, keadilan, keistimewaan dan kekhususan serta potensi dan keanekaragaman daerah dalam sistem Negara Kesatuan Republik Indonesia. ${ }^{3}$ Pemerintah juga memberikan kesempatan yang luas pada setiap warga negaranya untuk memperjuangkan hak-haknya secara kolektif, serta untuk mencapai cita-cita perjuangan bangsa, mewujudkan masyarakat yang adil dan makmur. ${ }^{4}$

1 Lihat Pasal 1 angka 2 Undang-Undang Nomor 23 Tahun 2014 tentang Pemerintahan Daerah sebagaimana telah diubah beberapa kali terakhir dengan Undang-Undang Nomor 9 Tahun 2015 tentang Perubahan atas Undang-Undang Nomor 23 Tahun 2014 tentang Pemerintahan Daerah.

2 Lihat Pasal 1 angka 6 dan angka 11 Undang-Undang Nomor 23 Tahun 2014 tentang Pemerintahan Daerah sebagaimana telah diubah beberapa kali terakhir dengan Undang-Undang Nomor 9 Tahun 2015 tentang Perubahan atas Undang-Undang Nomor 23 Tahun 2014 tentang Pemerintahan Daerah.

3 Lihat Penjelasan Umum Undang-Undang Nomor 23 Tahun 2014 tentang Pemerintahan Daerah.

4 Muh. Sabaruddin Sinapoy dan Safril Sofwan Sanib, "Pencabutan dan Pembatasan Hak Politik Warga Negara dalam Pemilu: Suatu Bentuk Pelanggaran Hak Asasi Manusia," Halu Oleo Law Review 3, no. 2 (2019): 283-298. 
Dalam perkembangan pelaksanaan otonomi daerah, keberadaan peraturan daerah belum dapat diaktualisasikan dengan baik. Hal ini ditunjukkan dengan banyaknya peraturan daerah yang menimbulkan permasalahan hukum. Salah satu contoh peraturan daerah yang dimaksud adalah Peraturan Daerah Kabupaten Konawe Nomor 7 Tahun 2011 tentang Perubahan atas Peraturan Daerah Nomor 2 Tahun 2011 tentang Pembentukan dan Pendefinisian Desa-Desa Dalam Wilayah Kabupaten Konawe. Peraturan daerah ini dibentuk hanya untuk memenuhi hasrat dan kepentingan segelintir orang atau kelompok orang, yang secara teknis yuridis pembentukannya bertentangan dengan prosedur pembentukan peraturan perundang-undangan sebagaimana ditegaskan dalam UndangUndang Nomor 15 Tahun 2019 tentang Perubahan Atas Undang-Undang Nomor 12 Tahun 2011 tentang Pembentukan Peraturan Perundang-undangan.

Pemerintah daerah ketika membentuk kebijakan daerah baik dalam bentuk peraturan daerah maupun kebijakan lainnya hendaknya juga memperhatikan kepentingan nasional. Dengan demikian, akan tercipta keseimbangan antara kepentingan nasional yang sinergis dan tetap memperhatikan kondisi, kekhasan, dan kearifan lokal dalam penyelenggaraan pemerintahan secara keseluruhan. Pemerintah pusat tidak mungkin berfungsi dengan baik tanpa ada pemerintah daerah, begitu juga sebaliknya karena kedua tingkat pemerintahan tersebut saling melengkapi untuk menyelenggarakan urusan dalam upaya mewujudkan tujuan negara. ${ }^{5}$

Pembentukan peraturan daerah merupakan wujud kewenangan yang diberikan kepada pemerintahan daerah dalam rangka penyelenggaraan otonomi daerah dan tugas pembantuan serta menampung kondisi khusus daerah dan/atau penjabaran lebih lanjut peraturan perundang-undangan yang lebih tinggi. Dengan demikian, kewenangan pembentukan peraturan daerah berada di tangan pemerintahan daerah. Pemerintahan daerah meliputi pemerintah daerah dan dewan perwakilan rakyat daerah. Peraturan daerah dibentuk oleh pemerintah daerah dengan persetujuan bersama dewan perwakilan rakyat daerah.

Dalam pembentukan peraturan daerah harus memenuhi syarat formal dan materiil. Syarat formal, berkaitan dengan tahapan atau prosedur pembentukan suatu peraturan perundang-undangan (peraturan daerah). Pembentukan suatu peraturan perundangundangan mencakup tahapan perencanaan, penyusunan, pembahasan, pengesahan atau penetapan dan pengundangan. Sedangkan, syarat materiil, berkaitan dengan materi muatan dalam suatu peraturan perundang-undangan. Materi muatan dalam suatu peraturan perundang-undangan adalah materi yang dimuat dalam peraturan perundangundangan sesuai jenis, fungsi, dan hierarki peraturan perundang-undangan.

Tahapan atau prosedur pembentukan suatu peraturan perundang-undangan (peraturan daerah) telah diatur dalam ketentuan peraturan perundang-undangan. Pengaturan mengenai tahapan atau prosedur pembentukan suatu peraturan daerah diatur dalam

5 Lili Romli, Potret Otonomi Daerah dan Wakil Rakyat di Tingkat Lokal (Yogyakarta: Pustaka Pelajar, 2007), 159. 
Undang-Undang Nomor 12 Tahun 2011 tentang Pembentukan Peraturan Perundangundangan sebagaimana telah diubah dengan Undang-Undang Nomor 15 Tahun 2019 tentang Perubahan Atas Undang-Undang Nomor 12 Tahun 2011 tentang Pembentukan Peraturan Perundang-undangan dan lebih lanjut dalam Peraturan Menteri Dalam Negeri Nomor 80 Tahun 2015 tentang Pembentukan Produk Hukum Daerah sebagaimana telah diubah dengan Peraturan Menteri Dalam Negeri Republik Indonesia Nomor 120 Tahun 2018 tentang Perubahan atas Peraturan Menteri Dalam Negeri Republik Indonesia Nomor 80 Tahun 2015 tentang Pembentukan Produk Hukum Daerah.

Fungsi peraturan daerah yaitu pertama, menyelenggarakan otonomi daerah dan tugas pembantuan, dan kedua menampung kondisi khusus daerah serta ketiga instrumen penjabaran peraturan perundang-undangan yang lebih tinggi. ${ }^{6}$

Menurut Lutfil Ansori, peranan peraturan daerah dalam otonomi daerah dapat dilihat dalam beberapa hal sebagai berikut: ${ }^{7}$

1. Peraturan daerah sebagai instrumen kebijakan dalam melaksanakan otonomi daerah yang luas dan bertanggungjawab.

2. Peraturan daerah merupakan pelaksana peraturan perundang-undangan yang lebih tinggi.

3. Peraturan merupakan penangkap dan penyalur aspirasi masyarakat daerah.

4. Peraturan daerah sebagai alat transformasi perubahan daerah.

Mengingat fungsi dan peranan peraturan daerah yang demikian penting, maka pembentukannya perlu direncanakan. Perencanaan pembentukan peraturan daerah dilakukan dalam program pembentukan peraturan daerah (propemperda). Propemperda adalah instrumen perencanaan program pembentukan peraturan daerah provinsi dan peraturan daerah kabupaten/kota yang disusun secara terencana, terpadu, dan sistematis. Melalui Propemperda diharapkan pembentukan peraturan daerah dapat terlaksana secara tertib, teratur, tersistematis, tidak tumpang tindih dan memperhatikan skala prioritas dalam pembentukan peraturan daerah.

Penyusunan propemperda provinsi dilakukan oleh DPRD Provinsi dan Pemerintah Daerah Provinsi; Sedangkan propemperda kabupaten/kota dilakukan oleh DPRD kabupaten/kota dan pemerintah daerah kabupaten/kota. Propemperda ditetapkan untuk jangka waktu 1 (satu) tahun berdasarkan skala prioritas pembentukan rancangan peraturan daerah. Penyusunan dan penetapan propemperda dilakukan setiap tahun sebelum penetapan rancangan peraturan daerah tentang Anggaran Pendapatan Belanja Daerah. ${ }^{8}$

Fakta menunjukkan bahwa sebagian besar daerah belum mengetahui prosedur dan mekanisme penetapan propemperda. Propemperda cenderung diabaikan dalam proses

\footnotetext{
Ahmad Redi, Hukum Pembentukan Peraturan Perundang-undangan (Jakarta: Sinar Grafika, 2018), 104.

Lutfil Ansori, Legal Drafting Teori dan Praktik Penyusunan Peraturan Perundang-undangan (Depok: Rajawali Pers, 2019), 75.

8 Lihat Pasal 34 Undang-Undang Nomor 12 Tahun 2011 tentang Pembentukan Peraturan Perundangundangan.
} 
pembentukan peraturan daerah. Akibatnya, propemperda ditetapkan setelah pengesahan atau penetapan rancangan peraturan daerah. Bahkan, masih banyak daerah yang sama sekali tidak menyusun propemperda.

Propemperda yang ditetapkan setelah penyusunan atau pengesahan rancangan peraturan daerah melanggar ketentuan peraturan perundang-undangan. Seyogyanya penyusunan dan penetapan propemperda dilakukan setiap tahun sebelum penetapan rancangan peraturan daerah.

Peraturan daerah yang berlaku tanpa melalui tahapan perencanaan dikhawatirkan menjadi cacat formal. Formal dalam hal tata cara pembentukan peraturan perundangundangan. Masalah formal pembentukan ini terkait dengan penyimpangan atas proses baku yang seharusnya ditaati secara tertib.

Berdasarkan penjelasan di atas, penulis perlu mengkaji mengenai "Analisis Hukum Peraturan Daerah Tanpa Melalui Tahapan Perencanaan Pembentukan Peraturan Perundang-undangan". Adapun yang menjadi permasalahan adalah bagaimana legalitas hukum peraturan daerah tanpa melalui tahapan perencanaan pembentukan peraturan perundang-undangan dan bagaimana tata cara pembatalan peraturan daerah yang tidak melalui tahapan perencanaan pembentukan peraturan perundang-undangan.

\section{Metode}

Penelitian ini adalah penelitian hukum normatif, yaitu penelitian yang dilakukan dengan menganalisis permasalahan dengan menggunakan asas-asas hukum dan prinsip-prinsip hukum. Peneliti menganalisis ketentuan-ketentuan yang menjadi dasar dan landasan bagi permasalahan yang dibahas dengan melakukan studi kepustakaan. Pendekatan penelitian hukum normatif yang digunakan adalah pendekatan perundang-undangan (statute approach), pendekatan konseptual (conceptual approach), dan pendekatan kasus (case approach).

Teknik pengumpulan bahan hukum yang berkaitan dengan penelitian ini adalah studi kepustakaan (library research). Studi kepustakaan adalah suatu alat pengumpulan bahan hukum yang dilakukan melalui bahan hukum tertulis dengan mempergunakan content analysis. ${ }^{9}$ Analisis bahan hukum yang digunakan adalah deskriptif analitis yaitu suatu penelitian yang bertujuan untuk mendeskripsikan tentang fakta dan kondisi atau gejala yang menjadi objek penelitian, setelah itu dilakukan telaah secara kritis, dalam arti memberikan penjelasan-penjelasan atas fakta atau gejala tersebut, baik dalam kerangka sistemisasi atau sinkronisasi, dengan berdasarkan pada aspek yuridis.

9 Peter Mahmud Marzuki, Penelitian Hukum (Jakarta: Kencana Prenada Media Group, 2011), 21. 


\section{Legalitas Hukum Peraturan Daerah Tanpa Melalui Tahapan Perencanaan Pembentukan Peraturan Perundang-undangan}

Perencanaan merupakan tahapan awal dalam suatu kegiatan atau tindakan pembentukan peraturan perundang-undangan. Perencanaan memegang peranan penting dalam menentukan keberhasilan pencapaian tujuan yang dicita-citakan (termasuk pembentukan peraturan daerah). Keberhasilan suatu kegiatan atau tindakan akan tergantung pada perencanaan yang telah dilakukan.

Dalam pembentukan peraturan perundang-undangan telah ditetapkan tahapan-tahapan yang harus dilalui organ pembentuk peraturan perundang-undangan. Tahapan perencanaan merupakan tahapan awal dari proses pembentukan peraturan perundangundangan.

Ketentuan Pasal 1 angka 1 Undang-Undang Nomor 12 Tahun 2011 tentang Pembentukan Peraturan Perundang-undangan sebagaimana telah diubah dengan Undang-Undang Nomor 15 Tahun 2019 tentang Perubahan Atas Undang-Undang Nomor 12 Tahun 2011 tentang Pembentukan Peraturan Perundang-undangan disebutkan bahwa pembentukan peraturan perundang-undangan adalah pembuatan peraturan perundang-undangan yang mencakup tahapan perencanaan, penyusunan, pembahasan, pengesahan atau penetapan, dan pengundangan.

Dalam konteks pembentukan peraturan daerah, ketentuan Pasal 239 ayat (1) UndangUndang Nomor 23 Tahun 2014 tentang Pemerintahan Daerah sebagaimana telah diubah beberapa kali terakhir dengan Undang-Undang Nomor 9 Tahun 2015 tentang Perubahan atas Undang-Undang Nomor 23 Tahun 2014 tentang Pemerintahan Daerah disebutkan bahwa perencanaan penyusunan peraturan daerah dilakukan dalam program pembentukan peraturan daerah. ${ }^{10}$

Program pembentukan peraturan daerah atau program legislasi daerah adalah instrumen perencanaan yang disusun secara terencana, terpadu, dan sistematis. ${ }^{11}$

Tahapan perencanaan pembentukan peraturan daerah diatur dalam peraturan perundang-undangan sebagai berikut:

10 Lihat juga ketentuan Pasal 32 dan Pasal 39 Undang-Undang Nomor 12 Tahun 2011 tentang Pembentukan Peraturan Perundang-undangan sebagaimana telah diubah dengan Undang-Undang Nomor 15 Tahun 2019 tentang Perubahan Atas Undang-Undang Nomor 12 Tahun 2011 tentang Pembentukan Peraturan Perundang-undangan, yang juga menyebutkan bahwa perencanaan penyusunan peraturan daerah provinsi dan kabupaten/kota dilakukan dalam program legislasi daerah.

11 Lihat ketentuan Pasal 1 Angka 10 Undang-Undang Nomor 12 Tahun 2011 tentang Pembentukan Peraturan Perundang-undangan sebagaimana telah diubah dengan Undang-Undang Nomor 15 Tahun 2019 tentang Perubahan Atas Undang-Undang Nomor 12 Tahun 2011 tentang Pembentukan Peraturan Perundang-undangan dan lihat juga ketentuan Pasal 1 angka 12 Peraturan Menteri Dalam Negeri Nomor 80 Tahun 2015 tentang Pembentukan Produk Hukum Daerah sebagaimana telah diubah dengan Peraturan Menteri Dalam Negeri Republik Indonesia Nomor 120 Tahun 2018 tentang Perubahan atas Peraturan Menteri Dalam Negeri Republik Indonesia Nomor 80 Tahun 2015 tentang Pembentukan Produk Hukum Daerah. 
1. Undang Nomor 12 Tahun 2011 tentang Pembentukan Peraturan Perundangundangan sebagaimana telah diubah dengan Undang-Undang Nomor 15 Tahun 2019 tentang Perubahan Atas Undang-Undang Nomor 12 Tahun 2011 tentang Pembentukan Peraturan Perundang-undangan. ${ }^{12}$

2. Undang-Undang Nomor 23 Tahun 2014 tentang Pemerintahan Daerah sebagaimana telah diubah beberapa kali terakhir dengan Undang-Undang Nomor 9 Tahun 2015 tentang Perubahan atas Undang-Undang Nomor 23 Tahun 2014 tentang Pemerintahan Daerah. ${ }^{13}$

Secara rinci mengenai tahapan perencanaan pembentukan peraturan daerah dapat dilihat dalam ketentuan Peraturan Menteri Dalam Negeri Republik Indonesia Nomor 80 Tahun 2015 tentang Pembentukan Produk Hukum Daerah sebagaimana telah diubah dengan Peraturan Menteri Dalam Negeri Republik Indonesia Nomor 120 Tahun 2018 tentang Perubahan atas Peraturan Menteri Dalam Negeri Republik Indonesia Nomor 80 Tahun 2015 tentang Pembentukan Produk Hukum Daerah, yang menyatakan bahwa perencanaan pembentukan peraturan daerah meliputi kegiatan: ${ }^{14}$

1. Penyusunan program pembentukan peraturan daerah (Propemperda):

a. Tahapan penyusunan daftar rancangan peraturan daerah;

b. Tahapan penyusunan daftar urutan berdasarkan skala prioritas;

c. Tahapan penyepakatan hasil penyusunan;

d. Tahapan penetapan Propemperda.

2. Perencanaan penyusunan rancangan perda kumulatif terbuka.

Rancangan peraturan daerah kumulatif terbuka merupakan rancangan peraturan daerah di luar daftar prioritas pada Propemperda yang dalam keadaan tertentu dapat diajukan penyusunannya. Penyusunan rancangan peraturan daerah daftar kumulatif terbuka terdiri atas: ${ }^{15}$

a. akibat putusan Mahkamah Agung;

b. Anggaran Pendapatan dan Belanja Daerah (APBD).

12 Lihat ketentuan Pasal 39-Pasal 41 Undang-Undang Nomor 12 Tahun 2011 tentang Pembentukan Peraturan Perundang-undangan sebagaimana telah diubah dengan Undang-Undang Nomor 15 Tahun 2019 tentang Perubahan Atas Undang-Undang Nomor 12 Tahun 2011 tentang Pembentukan Peraturan Perundang-undangan, yang mengatur perencanaan peraturan daerah provinsi dan perencanaan peraturan daerah kabupaten/kota.

13 Lihat ketentuan Pasal 239 Undang-Undang Nomor 23 Tahun 2014 tentang Pemerintahan Daerah sebagaimana telah diubah beberapa kali terakhir dengan Undang-Undang Nomor 9 Tahun 2015 tentang Perubahan atas Undang-Undang Nomor 23 Tahun 2014 tentang Pemerintahan Daerah, yang mengatur perencanaan dalam program pembentukan peraturan daerah.

14 Lihat Pasal 10 jo. Pasal 17 Peraturan Menteri Dalam Negeri Nomor 80 Tahun 2015 tentang Pembentukan Produk Hukum Daerah sebagaimana telah diubah dengan Peraturan Menteri Dalam Negeri Republik Indonesia Nomor 120 Tahun 2018 tentang Perubahan atas Peraturan Menteri Dalam Negeri Republik Indonesia Nomor 80 Tahun 2015 tentang Pembentukan Produk Hukum Daerah.

15 Lihat Pasal 16 ayat (4) jo. Pasal 17 Peraturan Menteri Dalam Negeri Nomor 80 Tahun 2015 tentang Pembentukan Produk Hukum Daerah sebagaimana telah diubah dengan Peraturan Menteri Dalam Negeri Republik Indonesia Nomor 120 Tahun 2018 tentang Perubahan atas Peraturan Menteri Dalam Negeri Republik Indonesia Nomor 80 Tahun 2015 tentang Pembentukan Produk Hukum Daerah. 
Selain daftar kumulatif terbuka itu, khusus untuk kabupaten/kota juga dapat memuat daftar kumulatif terbuka dalam Propemperda mengenai: ${ }^{16}$

a. penataan kecamatan; dan

b. penataan desa.

3. Perencanaan penyusunan rancangan peraturan daerah di luar program pembentukan peraturan daerah (Propemperda).

Dalam keadaan tertentu, Dewan Perwakilan Rakyat Daerah (DPRD) atau kepala daerah dapat mengajukan rancangan peraturan daerah di luar Propemperda karena alasan: 17

a. mengatasi keadaan luar biasa, keadaan konflik, atau bencana alam;

b. menindaklanjuti kerja sama dengan pihak lain;

c. mengatasi keadaan tertentu lainnya yang memastikan adanya urgensi atas suatu rancangan peraturan daerah yang dapat disetujui bersama oleh alat kelengkapan DPRD yang khusus menangani bidang pembentukan peraturan daerah dan unit yang menangani bidang hukum pada pemerintahan daerah; dan

d. perintah dari ketentuan peraturan perundang-undangan yang lebih tinggi setelah Propemperda ditetapkan.

Wewenang dan prosedur merupakan landasan bagi legalitas formal. Atas dasar legalitas formal lahirlah asas presumption iustae causa. Atas dasar itulah ketentuan Pasal 67 ayat (1) UU Nomor 5 Tahun 1986 tentang Peradilan Tata Usaha Negara, (telah dua kali diubah), disebutkan "Gugatan tidak menunda atau menghalangi dilaksanakannya keputusan Badan atau Pejabat Tata Usaha Negara serta tindakan keputusan Badan atau Pejabat Tata Usaha Negara yang digugat". ${ }^{18}$ Hakikat dan kepastian hukum dalam menentukan adanya inisiatif suatu pemerintah adalah memastikan dalam tindakan tersebut adanya prinsip legalitas hukum. ${ }^{19}$

Menurut Ahmad Redi, permasalahan pertama dalam pembentukan peraturan perundangundangan yaitu masalah formal dalam tata cara pembentukan peraturan perundangundangan. Masalah formal pembentukan ini terkait dengan penyimpangan atas proses baku yang seharusnya ditaati secara tertib dan absolut. ${ }^{20}$

Para pakar hukum, pada umumnya menyatakan bahwa salah satu ukuran dalam menentukan suatu peraturan perundang-undangan yang berkualitas dapat dilihat dari

16 Lihat Pasal 18 jo. Pasal 17 Peraturan Menteri Dalam Negeri Nomor 80 Tahun 2015 tentang Pembentukan Produk Hukum Daerah sebagaimana telah diubah dengan Peraturan Menteri Dalam Negeri Republik Indonesia Nomor 120 Tahun 2018 tentang Perubahan atas Peraturan Menteri Dalam Negeri Republik Indonesia Nomor 80 Tahun 2015 tentang Pembentukan Produk Hukum Daerah.

17 Lihat Pasal 16 ayat (5) jo. Pasal 17 Peraturan Menteri Dalam Negeri Nomor 80 Tahun 2015 tentang Pembentukan Produk Hukum Daerah sebagaimana telah diubah dengan Peraturan Menteri Dalam Negeri Republik Indonesia Nomor 120 Tahun 2018 tentang Perubahan atas Peraturan Menteri Dalam Negeri Republik Indonesia Nomor 80 Tahun 2015 tentang Pembentukan Produk Hukum Daerah.

18 Muh. Jufri Dewa, Hukum Administrasi Negara Dalam Perspektif Pelayanan Publik (Kendari: Unhalu Press, 2011), 81.

19 Oheo K Haris, "Good Governance (Tata Kelola Pemerintahan Yang Baik) Dalam Pemberian Izin Oleh Pemerintah Daerah di Bidang Pertambangan," Yuridika (2017): 60.

20 Redi, Hukum Pembentukan Peraturan Perundang-undangan, 197. 
tahapan pembentukan suatu peraturan perundang-undangan (aspek formal). Pembentukan suatu peraturan perundang-undangan termasuk peraturan daerah harus memenuhi aspek formal pembentukan peraturan perundang-undangan. Pembentukan peraturan daerah yang dilakukan tanpa melalui tahapan perencanaan akan berimplikasi pada ketidakjelasan tujuan dibentuknya suatu peraturan daerah.

Pembentukan peraturan daerah yang tidak melalui tahapan perencanaan merupakan suatu bentuk penyimpangan atas prosedur yang telah diatur dalam ketentuan peraturan perundang-undangan. Pembentukan suatu peraturan daerah mencakup tahapan perencanaan, penyusunan, pembahasan, pengesahan atau penetapan dan pengundangan. Pembentukan suatu peraturan daerah seyogyanya memenuhi tahapan pembentukan peraturan daerah. Pembentukan peraturan daerah yang dilakukan tanpa melalui tahapan perencanaan berarti bahwa dalam prosedur pembentukan peraturan daerah tersebut terdapat tahapan pembentukan yang tidak ditaati.

Dengan kata lain, pembentukan peraturan daerah yang tidak melalui tahapan perencanaan memiliki kesalahan prosedur (cacat prosedur). Cacat prosedur akan berdampak pada keabsahan suatu peraturan daerah. Peraturan daerah tersebut tetap sah dan berlaku tetapi tidak legitimate karena tidak mematuhi prosedur yang telah ditetapkan dalam ketentuan peraturan perundang-undangan.

Suatu peraturan daerah dapat dibatalkan karena peraturan daerah tersebut dinilai memiliki sesuatu kekurangan, baik formal maupun materiil. Peraturan daerah yang dilakukan tanpa melalui tahapan perencanaan dapat dibatalkan karena tidak memenuhi aspek formal pembentukan peraturan daerah. Peraturan daerah yang dilakukan tanpa melalui tahapan perencanaan tersebut dan akibat hukumnya dianggap ada sampai diadakan pembatalan oleh hakim. Segala akibat hukum yang ditimbulkan antara waktu mengadakannya sampai waktu pembatalannya menjadi sah. Setelah adanya pembatalan, maka peraturan daerah itu dan akibat hukumnya, dianggap tidak ada. Hal ini sesuai dengan asas praesumptio iustae causa yang menyatakan bahwa demi kepastian hukum, setiap keputusan tata usaha negara yang dikeluarkan harus dianggap benar menurut hukum, karenanya dapat dilaksanakan lebih dahulu selama belum dibuktikan sebaliknya dan dinyatakan oleh hakim administrasi sebagai keputusan yang bersifat melawan hukum $^{21}$.

Peraturan daerah yang dinyatakan batal oleh hakim harus segera dilakukan pencabutan. Jika hakim menilai peraturan daerah tersebut bertentangan dengan peraturan perundangundangan yang lebih tinggi, maka hakim dapat mengeluarkan putusan bahwa peraturan daerah tersebut tidak sah dan tidak berlaku untuk umum, serta memerintahkan kepada instansi yang bersangkutan segera melakukan pencabutan. Hal ini diatur dalam Pasal 31 Undang-Undang Nomor 5 Tahun 2004 tentang Perubahan Atas Undang-Undang Nomor 14

21 S.F. Marbun, Peradilan Administrasi Negara dan Upaya Administratif di Indonesia (Yogyakarta: FH UII Press, 2015), 222; dalam Vincent Suriadinata, "Asas Presumptio Iustae Causa Dalam Ktun: Penundaan Pelaksnaan Ktun Oleh Hakim Peradilan Umum,” Refleksi Hukum: Jurnal Ilmu Hukum 2, no. 2 (2018): 140. 
Tahun 1985 tentang Mahkamah Agung dan Pasal 6 ayat (2) Peraturan Mahkamah Agung Nomor 1 Tahun 2011 tentang Hak Uji Materiil.

Pejabat yang berhak membatalkan suatu peraturan daerah adalah lembaga Mahkamah Agung sesuai dengan kewenangan yang diberikan peraturan perundang-undangan. Undang-Undang Nomor 12 Tahun 2011 tentang Pembentukan Peraturan Perundangundangan menyebutkan bahwa dalam hal suatu Peraturan Perundang-undangan di bawah Undang-Undang diduga bertentangan dengan undang-undang, pengujiannya dilakukan oleh Mahkamah Agung. Hal ini dikuatkan dengan adanya Putusan Mahkamah Konstitusi Nomor 137/PUU-XIII/2015 dan Putusan Mahkamah Konstitusi Nomor 56/PUU-XIV/2016 yang menghilangkan kewenangan yang dimiliki oleh menteri dalam negeri dan gubernur dalam membatalkan suatu peraturan daerah.

Selama ini, pengujian peraturan perundang-undangan berupa peraturan daerah dapat dilakukan secara judicial review melalui Mahkamah Agung dan dapat dilakukan secara executive review melalui menteri dalam negeri dan gubernur. Peraturan daerah provinsi yang bertentangan dengan ketentuan peraturan perundang-undangan yang lebih tinggi, kepentingan umum, dan/atau kesusilaan dibatalkan oleh menteri dalam negeri. Sedangkan, peraturan daerah kabupaten/kota yang bertentangan dengan ketentuan peraturan perundang-undangan yang lebih tinggi, kepentingan umum, dan/atau kesusilaan dibatalkan oleh gubernur sebagai wakil Pemerintah Pusat. Dalam hal gubernur sebagai wakil pemerintah pusat tidak membatalkan peraturan daerah kabupaten/kota yang bertentangan dengan ketentuan peraturan perundang-undangan yang lebih tinggi, kepentingan umum, dan/atau kesusilaan, menteri dalam negeri membatalkan peraturan daerah kabupaten/kota.

\section{Tata Cara Pembatalan Peraturan Daerah yang Tidak Melalui Tahapan Perencanaan Pembentukan Peraturan Perundang-undangan}

Di Indonesia, wewenang Mahkamah Agung sebagai lembaga yang melakukan kekuasaan kehakiman diberi kewenangan oleh Undang-Undang Dasar Negara Republik Indonesia Tahun 1945 untuk melakukan pengujian peraturan perundang-undangan di bawah undang-undang terhadap undang-undang. Kewenangan demikian ini kemudian dikenal dengan istilah judicial review atau pengujian peraturan perundang-undangan oleh lembaga kehakiman.

Sejalan dengan hal itu, untuk menguji proses pembentukan suatu peraturan perundangundangan termasuk peraturan daerah diperlukan adanya suatu pengujian dalam bentuk judicial review. Judicial review tersebut berupa pembatalan peraturan daerah.

Tata cara pembatalan suatu peraturan daerah oleh Mahkamah Agung dimuat dalam beberapa peraturan di antaranya:

1. Pasal 20 ayat (3) Undang-Undang Nomor 48 Tahun 2009 tentang Kekuasaan Kehakiman; 
2. Pasal 31 Undang-Undang Nomor 5 Tahun 2004 tentang Perubahan Atas UndangUndang Nomor 14 Tahun 1985 tentang Mahkamah Agung;

3. Pasal 31A Undang-Undang Nomor 5 Tahun 2004 tentang Perubahan Atas UndangUndang Nomor 14 Tahun 1985 tentang Mahkamah Agung;

4. Pasal 31A Undang-Undang Nomor 3 Tahun 2009 Tentang Perubahan Kedua Atas Undang-Undang Nomor 14 Tahun 1985 Tentang Mahkamah Agung; dan

5. Peraturan Mahkamah Agung Nomor 1 Tahun 2011 tentang Hak Uji Materiil.

Saldi Isra, menggolongkan judicial review menjadi 2 (dua), yaitu pertama, objek yang berupa isi (bunyi pasal-pasal) dari sebuah peraturan perundang-undangan (material law), dan kedua, objek yang berupa prosedur pembentukan peraturan perundang-undangan (formal law). ${ }^{22}$

Dalam kaitannya dengan fungsi Mahkamah Agung yang bersifat peradilan (justitiele functie) ${ }^{23}$, Mahkamah Agung juga harus menguji apakah suatu peraturan perundangundangan termasuk peraturan daerah memperhatikan atau menuruti prosedur yang telah ditentukan oleh hukum. Sesuai dengan ketentuan peraturan perundang-undangan, Mahkamah Agung memiliki wewenang untuk menguji tahapan pembentukan suatu peraturan perundang-undangan (formal) dan menguji materi muatan suatu peraturan perundang-undangan (materiil).

Dalam keadaan demikian, maka Mahkamah Agung adalah lembaga kehakiman juga diberi tugas menyelesaikan konflik yang timbul dari proses lahirnya suatu produk peraturan perundang-undangan, termasuk peraturan daerah. Oleh karena itu, perlu ada penyempurnaan pada Peraturan Mahkamah Agung Nomor 1 Tahun 2011 tentang Hak Uji Materiil sebagai hukum acara pengujian peraturan perundang-undangan, yang tidak hanya memeriksa atau menguji aspek materi muatan tetapi juga memeriksa atau menguji aspek tahapan pembentukan peraturan perundang-undangan, termasuk peraturan daerah.

Pengawasan terhadap pembentukan peraturan daerah dalam Undang-Undang Nomor 23 Tahun 2014 tentang Pemerintahan Daerah menggunakan 2 (dua) model pengawasan yaitu pengawasan preventif dalam bentuk evaluasi rancangan peraturan daerah oleh

22 Saldi Isra et al., Perkembangan Pengujian Perundang-undangan di Mahkamah Konstitusi (Dari Berpikir Hukum Tekstual ke Hukum Progresif) (Jakarta dan Padang: Hasil Penelitian Kerjasama Mahkamah Konstitusi Republik Indonesia dengan Pusat Studi Konstitusi Fakultas Hukum Universitas Andalas, 2010), 5.

23 Mahkamah Agung mempunyai beberapa fungsi, yakni: Fungsi peradilan (justitiele functie); Fungsi pengawasan (Toeziende functie); Fungsi mengatur (Regelende functie); Fungsi penasihat (Advieserende functie); dan Fungsi administratif (Administratieve functie). Budiman B. Sagala, Praktek Sistem Ketatanegaraan Menurut UUD 1945 (Jakarta: Ghalia Indonesia, 1982), 157-158; dalam Kevin Angkouw, "Fungsi Mahkamah Agung Sebagai Pengawas Internal Tugas Hakim dalam Proses Peradilan," Lex Administratum II, no. 3 (2014): 138. 
pemerintah secara berjenjang, ${ }^{24}$ dan pengawasan represif dalam bentuk pembatalan peraturan daerah oleh pemerintah secara berjenjang. ${ }^{25}$

Keberadaan putusan Mahkamah Konstitusi Nomor 137/PUU-XIII/2015 dan Nomor 56/PUU-XIV/2016 yang membatalkan Pasal 251 Undang-Undang Nomor 23 Tahun 2014 tentang Pemerintahan Daerah membawa perkembangan baru dalam pemerintahan daerah. Dengan putusan Mahkamah Konstitusi tersebut menteri dalam negeri dan gubernur telah kehilangan kewenangan dalam pembatalan suatu peraturan daerah. Hal ini membawa dampak yang signifikan terhadap hubungan antara pusat dan daerah, terutama terkait dengan pengawasan.

Oleh karena itu, sebagai tindak lanjut dari putusan mahkamah konstitusi, pemerintah pusat melalui menteri dalam negeri menerbitkan Peraturan Menteri Dalam Negeri Republik Indonesia Nomor 120 Tahun 2018 tentang Perubahan atas Peraturan Menteri Dalam Negeri Republik Indonesia Nomor 80 Tahun 2015 tentang Pembentukan Produk Hukum Daerah yang mulai berlaku pada tanggal pada tanggal 20 Februari 2019. Dalam peraturan tersebut diatur mengenai instrumen pengawasan represif dilakukan melalui klarifikasi terhadap peraturan daerah.

Pengawasan terhadap pembentukan peraturan daerah dapat dilaksanakan melalui pengawasan preventif dalam bentuk evaluasi rancangan peraturan daerah dan dalam bentuk fasilitasi terhadap rancangan peraturan daerah. Fasilitasi dilakukan oleh Menteri melalui Direktur Jenderal Otonomi Daerah bagi provinsi dan gubernur bagi kabupaten/kota.

Sedangkan, pengawasan represif terhadap peraturan daerah dilakukan dalam bentuk pembatalan oleh Mahkamah Agung dan dalam bentuk klarifikasi oleh pemerintah secara berjenjang. Klarifikasi dilakukan oleh Direktorat Jenderal Otonomi Daerah melalui Direktorat Produk Hukum Daerah untuk peraturan daerah provinsi dan biro hukum provinsi untuk peraturan daerah kabupaten/kota.

\section{Kesimpulan}

Peraturan daerah yang tidak melalui tahapan perencanaan pembentukan peraturan perundang-undangan merupakan cacat prosedur atau kesalahan prosedur. Dengan dinyatakannya suatu peraturan daerah cacat prosedur, maka berarti peraturan daerah tersebut, sudah mempunyai kelemahan dalam kedayagunaan dan kehasilgunaan. Peraturan daerah yang tidak melalui tahapan perencanaan pembentukan peraturan perundang-undangan dapat dibatalkan karena pembentukannya tidak sesuai dengan

24 Lihat Pasal 245 ayat (1)-ayat (5) Undang-Undang Nomor 23 Tahun 2014 tentang Pemerintahan Daerah sebagaimana telah diubah beberapa kali terakhir dengan Undang-Undang Nomor 9 Tahun 2015 tentang Perubahan atas Undang-Undang Nomor 23 Tahun 2014 tentang Pemerintahan Daerah

25 Lihat Pasal 251 ayat (1), ayat (2), dan ayat (3) Undang-Undang Nomor 23 Tahun 2014 tentang Pemerintahan Daerah sebagaimana telah diubah beberapa kali terakhir dengan Undang-Undang Nomor 9 Tahun 2015 tentang Perubahan atas Undang-Undang Nomor 23 Tahun 2014 tentang Pemerintahan Daerah. 
ketentuan peraturan perundang-undangan. Terkait dengan tata cara pembatalan suatu peraturan daerah yang tidak melalui tahapan perencanaan pembentukan peraturan perundang-undangan dilakukan oleh Mahkamah Agung dalam bentuk judicial review. Pengawasan pemerintah terhadap pembentukan peraturan daerah dapat dilaksanakan melalui pengawasan preventif dalam bentuk evaluasi dan fasilitasi rancangan peraturan daerah secara berjenjang dan pengawasan represif dalam bentuk klarifikasi secara berjenjang.

\section{Daftar Pustaka}

Angkouw, Kevin. "Fungsi Mahkamah Agung Sebagai Pengawas Internal Tugas Hakim dalam Proses Peradilan." Lex Administratum II, no. 3 (2014): 125-134.

Ansori, Lutfil. Legal Drafting Teori dan Praktik Penyusunan Peraturan Perundangundangan. Depok: Rajawali Pers, 2019.

Dewa, Muh. Jufri. Hukum Administrasi Negara Dalam Perspektif Pelayanan Publik. Kendari: Unhalu Press, 2011.

Haris, Oheo K. "Good Governance (Tata Kelola Pemerintahan Yang Baik) Dalam Pemberian Izin Oleh Pemerintah Daerah di Bidang Pertambangan.” Yuridika (2017).

Isra, Saldi, Yuliandri, Feri Amsari, Charles Simabura, Dayu Medina, dan Edita Elda. Perkembangan Pengujian Perundang-undangan di Mahkamah Konstitusi (Dari Berpikir Hukum Tekstual ke Hukum Progresif). Jakarta dan Padang: Hasil Penelitian Kerjasama Mahkamah Konstitusi Republik Indonesia dengan Pusat Studi Konstitusi Fakultas Hukum Universitas Andalas, 2010.

Marbun, S.F. Peradilan Administrasi Negara dan Upaya Administratif di Indonesia. Yogyakarta: FH UII Press, 2015.

Marzuki, Peter Mahmud. Penelitian Hukum. Jakarta: Kencana Prenada Media Group, 2011.

Redi, Ahmad. Hukum Pembentukan Peraturan Perundang-undangan. Jakarta: Sinar Grafika, 2018.

Romli, Lili. Potret Otonomi Daerah dan Wakil Rakyat di Tingkat Lokal. Yogyakarta: Pustaka Pelajar, 2007.

Sagala, Budiman B. Praktek Sistem Ketatanegaraan Menurut UUD 1945. Jakarta: Ghalia Indonesia, 1982.

Sinapoy, Muh. Sabaruddin, dan Safril Sofwan Sanib. "Pencabutan dan Pembatasan Hak Politik Warga Negara dalam Pemilu: Suatu Bentuk Pelanggaran Hak Asasi Manusia." Halu Oleo Law Review 3, no. 2 (2019).

Suriadinata, Vincent. “Asas Presumptio Iustae Causa Dalam Ktun: Penundaan Pelaksnaan Ktun Oleh Hakim Peradilan Umum.” Refleksi Hukum: Jurnal Ilmu Hukum 2, no. 2 (2018): 139-152. 